\title{
ANALISIS TEBAL PERKERASAN DAN BIAYA DENGAN SOFTWARE FAARFIELD PADA LANDAS PACU BIJB KERTAJATI
}

\author{
Silvani Desy Palino ${ }^{[1]}$, Budi Hartanto Susilo ${ }^{[2]}$ \\ ${ }^{[1]}$ Alumni, Program Studi Teknik Sipil, Fakultas Teknik, Universitas Kristen Maranatha \\ ${ }^{[2]}$ Guru Besar, Program Studi Teknik Sipil, Fakultas Teknik, Universitas Kristen Maranatha \\ Jurusan Teknik Sipil, Fakultas Teknik, Universitas Kristen Maranatha Bandung \\ Jl. Prof. Drg. SoeriaSoemantri No. 65 Bandung 40164 \\ E-mail: silvanidesyppp@gmail.com, budiharsus@yahoo.com
}

\begin{abstract}
ABSTRAK
Suatu bandara yang telah dibangun dan digunakan untuk lalu lintas udara tentu penting adanya tindakan analisis dan evaluasi ketebalan yang dapat menahan beban pergerakan lalu lintas. Maka, maksud dari penelitian ini yakni menganalisis tebal perkerasan landas pacu dengan metode FAA Advisory Circular No. 150/5320-6E melalui perangkat lunak FAARFIELD dimana hasil analisis didapat total tebal perkerasan 814,9 mm dengan tebal lapisan permukaan sebesar $200 \mathrm{~mm}$, lapisan fondasi sebesar $127 \mathrm{~mm}$, dan tebal lapisan fondasi bawah sebesar 487,9 mm. Evaluasi ketebalan atas kekuatan struktur yaitu nilai PCN oleh dua metode yakni metode ICAO dan FAA berdasarkan AC 150/5335-5C dengan menggunakan perangkat lunak COMFAA dan memperhitungkan nilai ACN, yaitu angka yang menjadi suatu batasan pesawat tertentu terhadap perkerasan. Nilai PCN metode ICAO sebesar 89/F/C/X/T < ACN sebesar 89,3 sedangkan nilai PCN metode FAA sebesar $101,4 / \mathrm{F} / \mathrm{C} / \mathrm{X} / \mathrm{T}>\mathrm{ACN}$ sebesar 89,3. Hasil analisis biaya konstruksi dengan anggaran terendah dari kelima pembanding yakni pada metode perangkat lunak FAARFIELD sebesar Rp.326.252.664.418,00.
\end{abstract}

Kata kunci: ACN, Bandara, Biaya Konstruksi, FAARFIELD, PCN.

\begin{abstract}
An airport that was constructed and used for air traffic certainly repented of the action of thickness analysis and evaluation of thickness that could withstand the burden of traffic movements. Accordingly, the purpose of this research is to analyse runway pavement thickness that used is FAA Method Advisory Curcular no. 150/5320-6E through FAARFIELD software and the result is a total thickness of 814, 9mm with surface course thickness of $200 \mathrm{~mm}$, base course thickness of $127 \mathrm{~mm}$, and subbase course thickness of 487,9 mm. Evaluation thickness the stucture strength which is PCN score through two methods ICAO and FAA based on AC 150/5335-5C by using COMFAA software and by calculating ACN score which is the number that become a certain aircraft limitation toward the pavement.PCN score ICAO method is $89 / \mathrm{F} / \mathrm{C} / \mathrm{X} / \mathrm{T}<\mathrm{ACN}$ is 89,3 and FAA method is $101,4 / \mathrm{F} / \mathrm{C} / \mathrm{X} / \mathrm{T}>\mathrm{ACN}$ is 89,3 . The result of mininum construction cost analysis from 5 comparative is a method of software FAARFIELD of Rp.326.252.664.418,00.
\end{abstract}

Keywords: ACN, Airport, Construction Cost, FAARFIELD, PCN.

\section{PENDAHULUAN}

Bandara Internasional Jawa Barat (BIJB) Kertajati merupakan bandara terbaru di Jawa Barat yang baru dioperasionalkan dengan memindahkan rute penerbangan dari 
Bandara Husein Sastranegara ke Bandara BIJB. Sebelum BIJB dioperasionalkan pertumbuhan jumlah penumpang di Bandara Husein Sastranegara meningkat pesat sehingga mengakibatkan Bandara tersebut kelebihan kapasitas. Maka, hal tersebutlah yang menjadi awal mula dioperasionalkannya BIJB sebagai solusi dari masalah tersebut.

Peningkatan kebutuhan masyarakat terhadap fasilitas penerbangan mengharuskan adanya pemenuhan kebutuhan tersebut secara tepat sebagai contoh adalah pesawat jenis Boeing 747 dan Airbus A380-800. Oleh karena itu, perkerasan landas pacu harus memiliki tebal lapisan yang mampu menampung aktivitas pergerakan pesawat. Bandara dalam masa konstruksinya tentu lebih mengedepankan dan mengutamakan mengenai konstruksi perkerasan landas pacu. Perkerasan landas pacu menjadi peran utama dalam kegiatan lalu lintas udara yakni kegiatan lepas landas dan mendarat disebuah landasan yang telah direncanakan. Perkerasan landas pacu setiap bandara memiliki tebal lapisan struktur perkerasan yang mumpuni untuk digunakan selama kegiatan lalu lintas sesuai dengan umur rencana perkerasan.

Kekuatan dari lapisan struktur perkerasan tentu mengalami masa penurunan akibat kegiatan lalu lintas yang tinggi. Dalam hal ini, dibutuhkan tebal lapisan yang mengharuskan adanya analisis mengenai tebal lapisan itu sendiri dikarenakan perkerasan landas pacu harus memiliki tebal lapisan yang mampu menampung aktivitas pergerakan pesawat. Hal ini, berguna sebagai penahan beban pesat yang akan berpengaruh terhadap tebal perkerasan landas pacu BIJB. Dengan begitu, perlu adanya evaluasi mengenai pengembangan dimensi landas pacu dan tebal perkerasan landas pacu BIJB.

Perumusan masalah dalam penelitian ini yakni Bagaimana menganalisis tebal lapisan perkerasan landas pacu dengan software FAARFIELD, apakah perkerasan landas pacu yang direncanakan memenuhi standar, dan bagaimana menghitung biaya konstruksi untuk perkerasan landas pacu.

\section{TINJAUAN PUSTAKA}

Perkerasan bandara dirancang, dibangun dan dipelihara untuk mendukung beban kristis yang dibebani oleh pesawat terbang. Perkerasan bandara menghasilkan perkerasan yang kuat, stabil, kekesatan (skid resistance). Kualitas dan ketebalan perkerasan harus dipastikan bahwa perkerasan tidak akan gagal saat dibebani dan perkerasan harus cukup tahan lama untuk menahan tindakan abrasif pergerakan lalu lintas udara, kondisi cuaca yang buruk dan pengaruh buruk lainnya pada perkerasan. Maka, untuk memastikan kekuatan yang diperlukan perkerasan dan untuk mencegah kerusakan pada perkerasan 
maka bandara harus mempertimbangkan berbagai desain, konstruksi, dan bahan parameter yang berhubungan dengan material yang digunakan pada perkerasan bandara.

Secara umum perkerasan terdapat 2 tipe yaitu lentur dan kaku. Perkerasan lentur (flexible pavement) adalah suatu perkerasan yang berbahan dasar dari campuran aspal dan agregat yang terdiri atas surface, base course, subbasee course, dan subgrade. Namun, perkerasan kaku (rigid pavement) adalah struktur perkerasan yang terbuat oleh material campuran semen serta agregat yang terdiri atas slab-slab yang memiliki ketebalan sesuai dengan perencanaan.

Prinsip dari program FAARFIELD adalah menghitung tebal rencana perkerasan landas pacu yang didasarkan atas analisa struktur lapis secara tiga dimensi. Perhitungan dibuat untuk mengakomodasi dampak susunan sumbu roda pesawat yang rumit. Metode perencanaan membutuhkan perhitungan yang kompleks, sehingga FAA mengembangkan program komputer yang dinamakan FAARFIELD.

International Civil Aviation Organization (ICAO, 1983) menyatakan bahwa kekuatan struktur perkerasan yang direncanakan untuk pengoperasian pesawat udara yang memiliki berat total lebih dari $5700 \mathrm{~kg}$ harus dapat dipublikasikan dengan menggunakan metoda Aircraft Classification Number - Pavement Classification Number (ACN-PCN). Pavement Classification Number (PCN) adalah suatu angka yang menjelaskan daya dukung perkerasan untuk operasi pesawat tak terbatas, dengan nilai ACN kurang dari atau sama dengan PCN (ICAO,2016). Jika nilai ACN dan tekanan roda pesawat lebih besar dari nilai PCN pada kategori subgrade tertentu yang dipublikasikan, maka operasi pesawat udara tidak diijinkan beroperasi kecuali dengan mengurangi beban operasi, atau pada keadaan tertentu seperti, operasi penerbangan yang cukup padat sehingga pengoperasian kondisi overload dapat diberikan. Program

Aircraft Classification Number (ACN) merupakan sebuah angka yang menerangkan batasan pesawat khusus diatas perkerasan melalui perincian standard subgrade (ICAO,2016). Nilai ACN dikeluarkan oleh pabrik pembuat pesawat.

COMFAA adalah suatu program komputer dengan tujuan untuk melakukan perhitungan Aircraft Classification Number (ACN) dan perhitungan desain perkerasan. Program COMFAA dikembangkan dengan konsep Cummulative Damage Factor (CDF), yaitu dengan menghitung efek gabungan dari beberapa pesawat yang beroperasi di bandara. Efek dari lalu lintas gabungan ini disetarakan dengan pesawat kritis. Dengan penyetaraan tersebut, perhitungan PCN dapat mencakup dampak dari semua lalu lintas pesawat secara proporsional. 


\section{METODOLOGI PENELITIAN}

Pada penelitian diperlukan kerangka pemikiran atau diagram alir penelitian untuk mendukung dalam keberlangsungan penelitian agar mencapai suatu tujuan yang telah ditetapkan. Tahapan proses yang akan dilakukan dalam penelitian ini dapat dilihat pada Gambar 1.

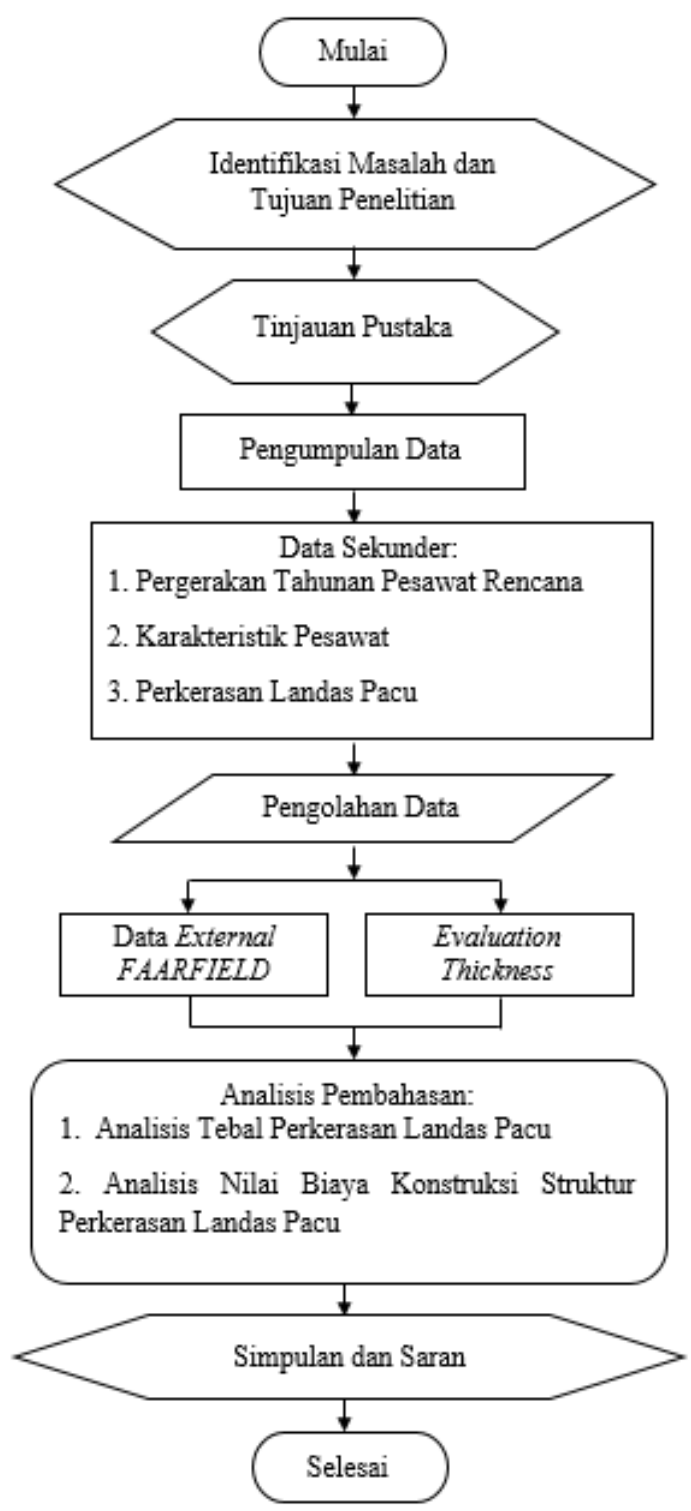

Gambar 1. Diagram Alir Penelitian

Pada Gambar 2 adalah alir penggunaan program FAARFIELD untuk melakukan perhitungan dan menghasilkan desain tebal perkerasan. Dengan meng-input data umur rencana, nilai CBR atau modulus elastisitas, traffic mix, dan jenis lapisan subbase dan base course yang akan digunakan dalam perencanaan. Metode perencanaan FAA 150/5320-6E 
adalah menetukan susunan dan evaluasi lapisan-lapisan tanah dasar dengan menggunakan software FAARFIELD.

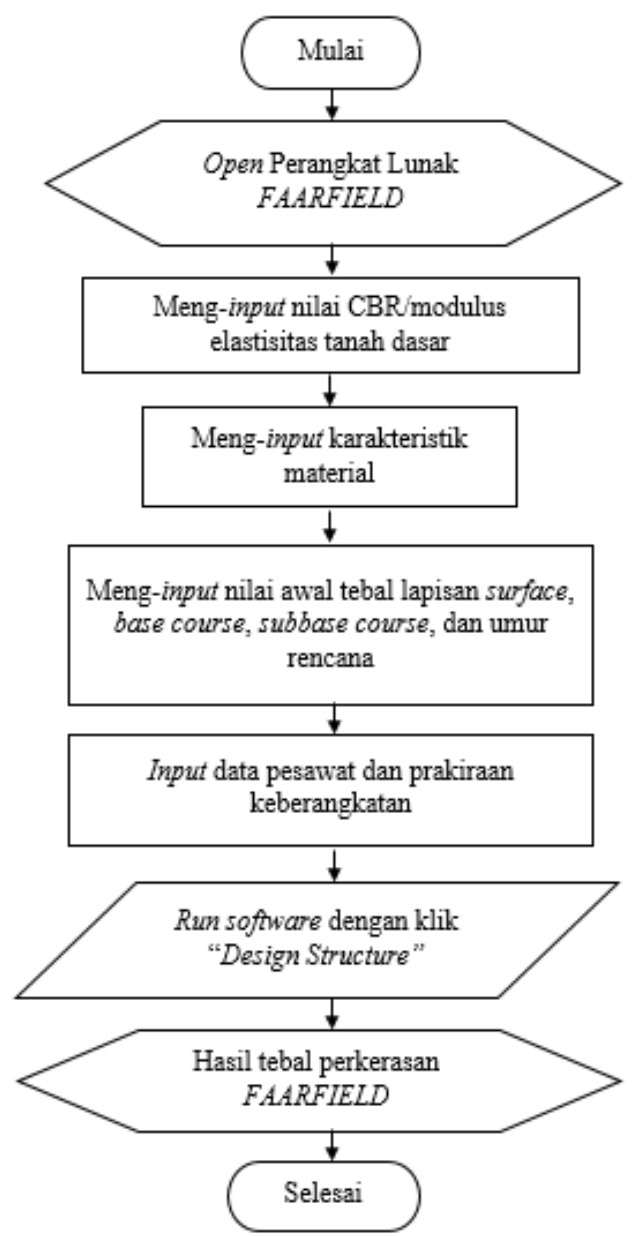

Gambar 2. Diagram Alir FAARFIELD

\section{HASIL DAN PEMBAHASAN}

Hasil analisis lapisan struktur perkerasan landas pacu BIJB Kertajati dengan menggunakan software FAARFIELD. Data pesawat dalam external library FAARFIELD yang menjadi data utama karakteristik rencana pesawat diperoleh secara langsung dari kelompok pesawat. Data karakteristik pesawat rencana yang digunakan terdiri atas berat kotor pesawat (gross taxi weight), annual departure ini dapat disesuaikan dengan asumsi pesawat rencana, persen pertumbuhan tahunan, total keberangkatan, nilai konstribusi kumulatif faktor kerusakan, cummulative damage factor (CDF) Max for Airplane, P/C ratio, Tire Press, Percent of GW on Gear, Dual Spacing, Tandem Spacing, Tire Contact Width, Tire Contact Length, Tire Contact Area. Data struktur perkerasan landas pacu BIJB diperoleh dari PT. Angkasa Pura II. Struktur perkerasan lentur terdiri atas 4 lapisan, yaitu: lapisan permukaan (surface) memakai bahan Hot Mix Asphalt (HMA) dengan tebal 200 
mm, lapisan fondasi (base course) dengan jenis Cement Treated Base Course (CTBC) dengan tebal $350 \mathrm{~mm}$, lapisan fondasi bawah (subbase course) dengan jenis Crushed Aggregate Course dengan tebal $460 \mathrm{~mm}$, dan lapisan tanah dasar yaitu subgrade dengan nilai CBR (California Bearing Ratio) yaitu nilai perbandingan antara berat bahan penetrasi pada perkerasan atas bahan standar pada kedalaman dan kecepatan penetrasi yang sama dengan nilai CBR sebesar 6\%. Data Asumsi Annual Departure untuk kebutuhan data analisis menggunakan software FAARFIELD dapat dilihat pada Tabel 1 dan Pokok data perkerasan landas pacu dapat dilihat pada Tabel 2.

Tampak detail dari potongan melintang perkerasan landas pacu dapat dilihat pada Gambar 3, serta dapat dilihat sketsa potongan memanjang perkerasan landas pacu BIJB pada Gambar 4 dan pada Gambar 5 ialah Hasil Analisis software FAARFIELD.

Tabel 1. Asumsi Annual Departure

\begin{tabular}{ccc}
\hline No & Jenis Pesawat & Annual Departure \\
\hline 1 & $B 747-100$ & 1.444 \\
2 & $B 737-300$ & 1.244 \\
3 & $B 777-300$ & 894 \\
4 & $B 747-400$ & 684 \\
5 & $B 767-300$ & 6.503 \\
6 & $A-320$ & 33.867 \\
7 & $A 319-100$ & 32.789 \\
8 & $B 737-800$ & 44.765 \\
9 & $B 737-900$ & 37.136 \\
\hline \multicolumn{2}{c}{ Sumber: Putri, 2016 }
\end{tabular}

Tabel 2. Data Perkerasan Landas Pacu BIJB

\begin{tabular}{ccc}
\hline Klasifikasi Lapisan & Tebal $(\mathrm{mm})$ & CBR $(\%)$ \\
\hline Surface & 200 & - \\
Base Course & 350 & - \\
Subbase Course & 460 & - \\
Subgrade & - & 6 \\
\hline
\end{tabular}

Sumber: PT. Angkasa Pura II, 2019 


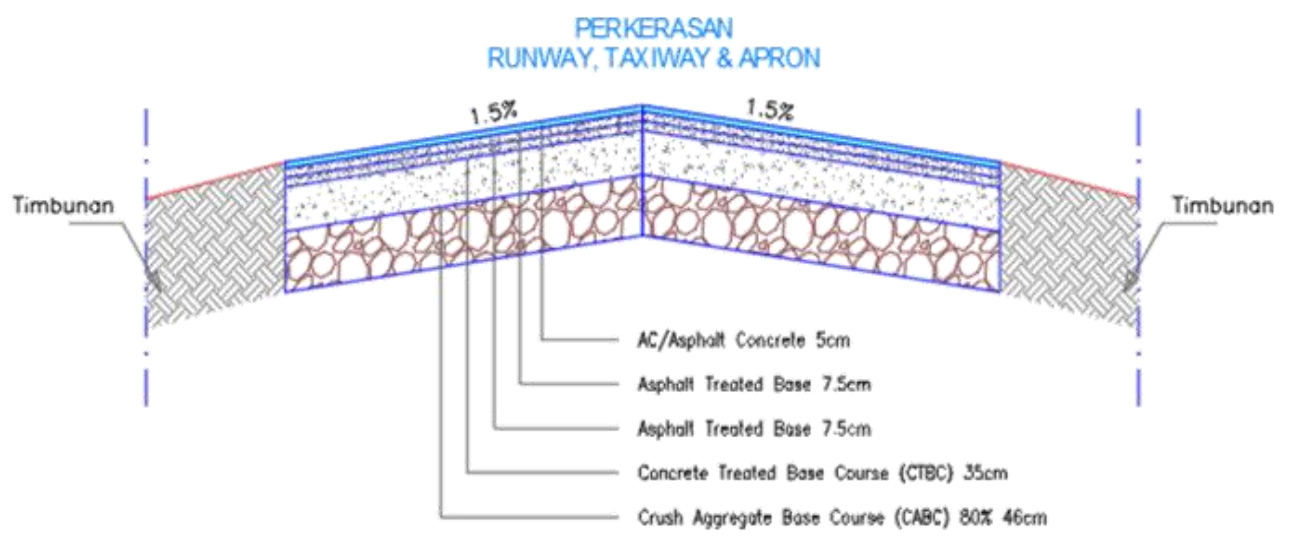

Gambar 3. Potongan Melintang Perkerasan Landas Pacu BIJB

Sumber: PT. Angkasa Pura II, 2019

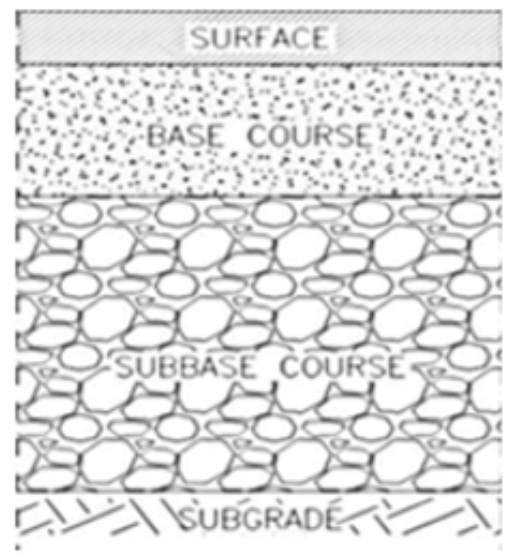

$200 \mathrm{~mm}$

$350 \mathrm{~mm}$

$460 \mathrm{~mm}$

$6 \%$

Gambar 4. Hasil Analisis Software FAARFIELD

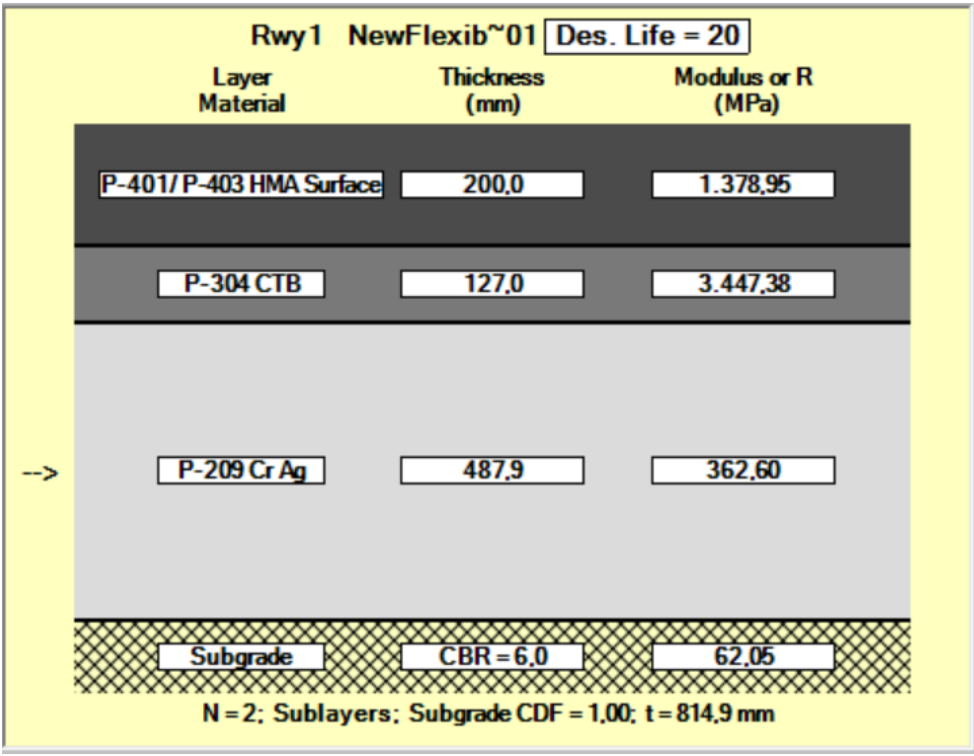

Gambar 5. Hasil Analisis Software FAARFIELD 
Tabel 3. Data Perkerasan Bandara

\begin{tabular}{cccccc}
\hline \multicolumn{5}{c}{ Data Struktur Perkerasan } \\
\hline \multirow{2}{*}{ No } & Type & Thickness & Modulus & Poisson's & Strength \\
& (mm) & $($ MPa $)$ & Ratio & $\boldsymbol{R},(\boldsymbol{M P a})$ \\
\hline 1 & $P-401 / P-403 \mathrm{HMA}$ & 200 & 1.379 & 0,35 & 0,00 \\
2 & $P-304 \mathrm{CTB}$ & 127 & 3.447 & 0,20 & 0,00 \\
3 & $P-209 \mathrm{Cr} \mathrm{Ag}$ & 487,9 & 362,60 & 0,35 & 0,00 \\
4 & Subgrade & 0,00 & 62,05 & 0,35 & 0,00 \\
\hline
\end{tabular}

Total ketebalan lapisan $=814,9 \mathrm{~mm}$

Seperti yang sudah tertera pada Tabel 3. Data Struktur Perkerasan hasil FAARFIELD. Berikut saya lampirkan Penampang Melintang Hasil Analisis FAARFIELD pada Gambar 6.

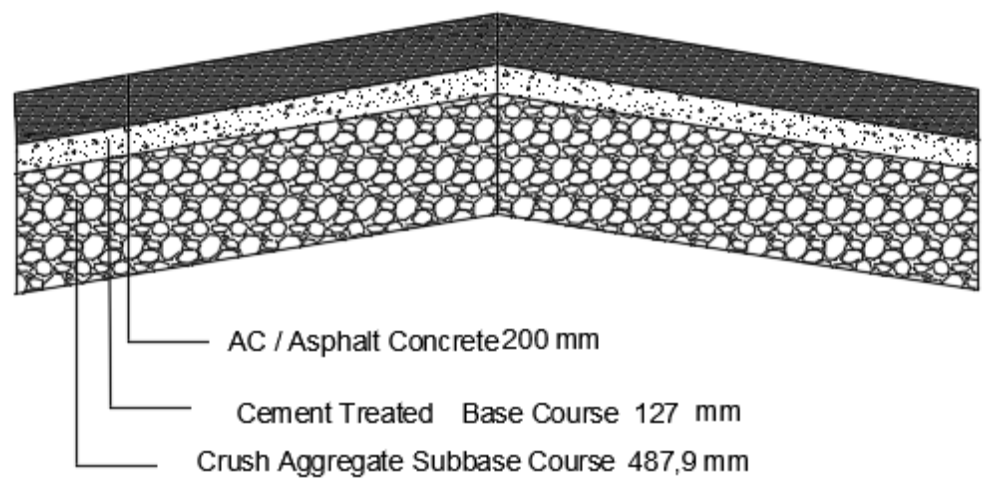

Gambar 6. Penampang Melintang Hasil Analisis FAARFIELD

\subsection{Evaluasi Ketebalan Perkerasan Landas Pacu BIJB}

Mengevaluasi tebal landas pacu (evaluation thickness) BIJB Kertajati dilakukan dengan mengacu pada metode FAA AC 150/5335-5C menggunakan software COMFAA sebagai software penunjang saat menganalisis kekuatan. Dalam menyelesaikan perhitungan nilai PCN dan ACN diselesaikan dengan spreadsheet microsoft excel yang telah diunduh dari situs resmi yaitu website FAA sebagai acuan untuk mempermudah proses perhitungan.

\subsection{Perhitungan Nilai Pavement Classification Number}

Dari hasil kalkulasi desain struktur mengenai tebal perkerasan landas pacu BIJB Kertajati dengan metode FAA menggunakan software FAARFIELD, kemudian menganalisis nilai pavement classification number $(\mathrm{PCN})$ dengan metode ICAO dan metode FAA yang berlandaskan AC 150/5335-5C melalui perangkat lunak COMFAA. 


\subsubsection{Metode ICAO}

Pengkalkulasian nilai PCN dengan metode ICAO, berlandaskan konsep dasar perhitungan berdasarkan pesawat kritis, nilai CBR perkerasan, faktor konversi keberangkatan tahunan. Perhitungan nilai PCN BIJB hasil analisis FAARFIELD, dilakukan sesuai prosedur perhitungan sebagai berikut:

Menentukan kebutuhan perkerasan, didapat tebal total perkerasan adalah $814,9 \mathrm{~mm}$.

$$
\begin{array}{ll}
\text { Lapisan Permukaan } & =200 \mathrm{~mm} \\
\text { Lapisan Fondasi } & =127 \mathrm{~mm} \\
\text { Lapisan Fondasi Bawah } & =487,9 \mathrm{~mm} \\
\text { Total } & =814,9 \mathrm{~mm}
\end{array}
$$

Menghitung tebal ekuivalen perkerasan, dijabarkan pada Tabel 4.

Tabel 4. Tebal Ekuivalen Perkerasan

\begin{tabular}{ccccc}
\hline No & Lapis Perkerasan & Tebal $(\mathrm{mm})$ & Bahan & Tebal Ekuivalen $(\mathrm{mm})$ \\
\hline 1 & Lapisan Permukaan & 200 & AC & $200 \times 1=200$ \\
2 & Lapisan Fondasi & 127 & BC & $127 \times 1=127$ \\
3 & Lapisan Fondasi Bawah & 487,9 & SB & $487,9 \times 1=487,9$ \\
Total & & & & $814,9 \mathrm{~mm}$ \\
\hline
\end{tabular}

Total Equivalent Thickness $=814,9 \mathrm{~mm}$

1. Menghitung beban yang diperbolehkan, Allowable Load (Po), untuk jenis pesawat B777- 300ER yakni sebesar $718.414 \mathrm{lbs}$.

2. Menghitung nilai PCN untuk pesawat B777- 300ER

Beban massa maksimum $=718.414 \mathrm{lbs}$

Beban massa minimum $=370.000 \mathrm{lbs}$

Nilai ACN maksimum $=89$

Nilai ACN minimum $=29$

Maka, $\mathrm{PCN}=\mathrm{ACNmin}+(\mathrm{ACNmax}-\mathrm{ACNmin})=$

$\mathrm{PCN}=29+(89-29)=$

$\mathrm{PCN}=89$

\subsubsection{Metode FAA}

Pengkalkulasian nilai PCN BIJB berdasarkan metode FAA AC 150/5335-5C oleh perangkat lunak COMFAA, melalui perhitungan dengan bantuan spreadsheet yang diunduh pada website resmi FAA. Cara perhitungannya ialah dengan menginput data tebal perkerasan eksisting dan faktor konversi pada sheet layer equivalency. Berikut prosedur 
dalam perhitungan metode ini, langkah awal ialah mengkonversi tebal lapisan melalui perangkat lunak COMFAA. Pada spreadsheet untuk perhitungan evaluation thickness dapat dilihat hasil dari perhitungan konversi tebal perkerasan pada Gambar 7 dengan tebal $1.189 \mathrm{~mm}$ dengan kriteria minimal lapisan beraspal (material P-401/3) serta lapisan pondasi (material P-209) berdasarkan standar FAA.

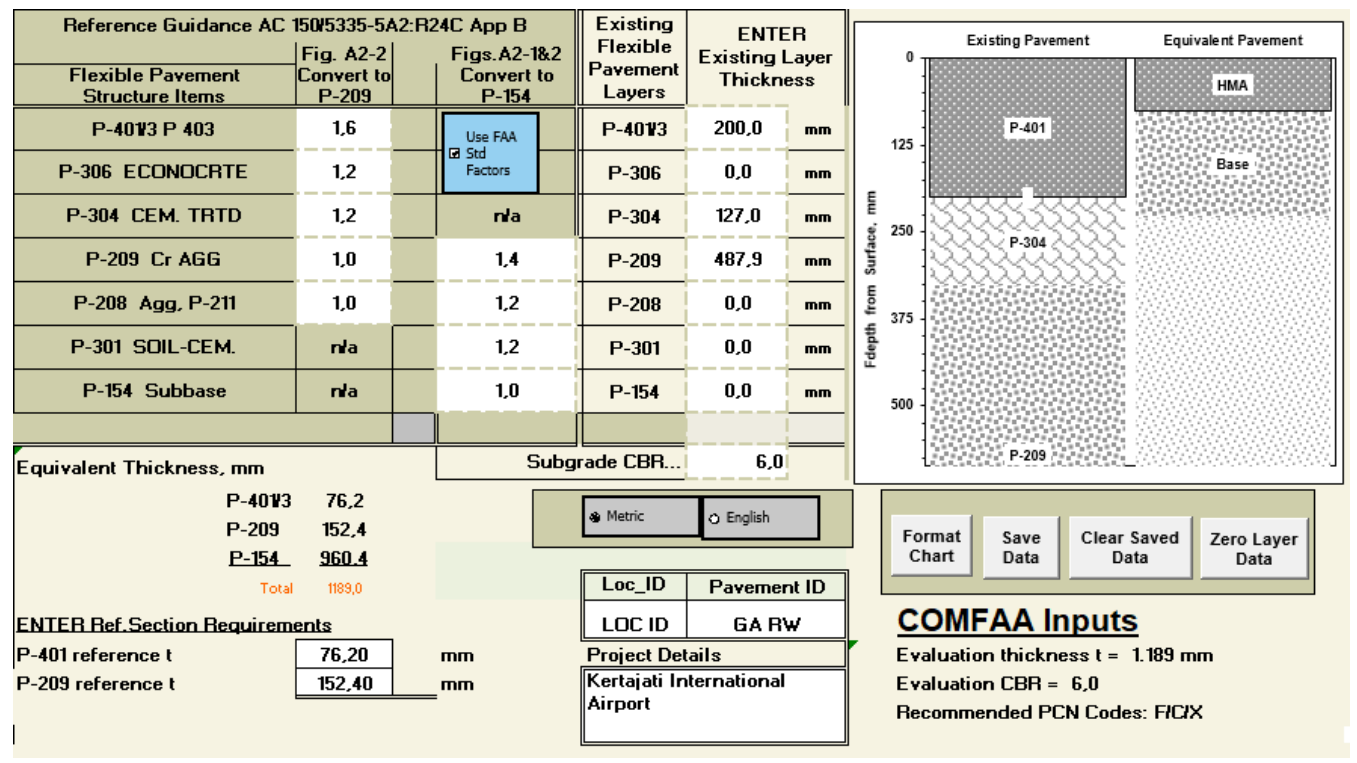

Gambar 7. Spreadsheet Evaluation Thickness

Hasil perhitungan nilai PCN berdasarkan metode FAA AC 150/5335-5C menggunakan perangkat lunak COMFAA, untuk perkerasan landas pacu yang telah dianalisis mendapat nilai terbesar ialah 101,4. Tipe perkerasan yang digunakan pada landas pacu ialah perkerasan lentur (flexible) sehingga kode yang dipakai ialah F. Nilai CBR pada tanah dasar (subgrade) ialah 6\% dan nilai CBR ini termasuk ke dalam kategori rendah (low) sehingga kode yang dipakai ialah C. Tekanan roda ban pesawat rencana (tire pressure) terbesar yang dianalisis yaitu 1.165 KPa atau 1,2 MPa yang dimiliki oleh pesawat B777300 ER dan termasuk ke dalam kategori X. Perhitungan nilai PCN dalam hal ini menggunakan metode teknis sehingga kode yang digunakan ialah T. Maka, kesimpulan dari hasil perhitungan PCN pada landas pacu BIJB Kertajati dapat dilihat pada Gambar 6 ialah 101,4/F/C/X/T. Maka perbandingan hasil perhitungan landas pacu dengan metode ICAO dan metode FAA AC 150/5335-5C menggunakan perangkat lunak COMFAA dapat dilihat pada Tabel 5 . 


\begin{tabular}{|c|c|c|c|c|c|c|c|c|}
\hline No. & Aircraft & Name & $\begin{array}{l}\text { Critical } \\
\text { Aircraft Total } \\
\text { Equiv. Covs. }\end{array}$ & $\begin{array}{l}\text { Thickness } \\
\text { for Total } \\
\text { Equiv. Covs. }\end{array}$ & $\begin{array}{c}\text { Maximum } \\
\text { Allowable } \\
\text { Gross Weight }\end{array}$ & $\begin{array}{c}\text { ACN Thick at } \\
\text { Max. Allowable } \\
\text { Gross Weight }\end{array}$ & $\mathrm{CDE}$ & $\begin{array}{c}\text { PCN on } \\
C(6)\end{array}$ \\
\hline 1 & $A-320 B \circ g$ & gie & $>5,000,000$ & 798,2 & 131,897 & 876,38 & 0,0000 & 57,4 \\
\hline 2 & A3 $319-100$ & std & $>5,000,000$ & $1.158,2$ & 67,397 & 717,76 & 0,0000 & 38,5 \\
\hline 3 & B737-900 & $\mathrm{IR}$ & $>5,000,000$ & $1.143,0$ & 91,542 & 903,62 & 0,0038 & 61,0 \\
\hline 4 & B737-800 & & $>5,000,000$ & $1.158,2$ & 83,010 & 843,85 & 0,0002 & 53,2 \\
\hline 5 & B7 $67-300$ & $\mathrm{ER}$ & 1.233 .010 & $1.143,2$ & 197,341 & 976,66 & 0,0092 & 71,3 \\
\hline 6 & B7 $47-400$ & & 149.986 & $1.122,9$ & 429,084 & 1044,54 & 0,0083 & 81,6 \\
\hline 7 & B777-300 & IR & 15.845 & $1.115,4$ & 381,150 & 1164,97 & 0,1370 & 101,4 \\
\hline 8 & B737-300 & & $>5,000,000$ & $1.168,3$ & 65,554 & 734,94 & 0,0000 & 40,4 \\
\hline \multirow[t]{2}{*}{9} & B747-100 & SF & $>5,000,000$ & $1.180,8$ & 337,871 & 863,79 & 0,0000 & 55,8 \\
\hline & & & & & & Total $C D F=$ & 0,1585 & \\
\hline
\end{tabular}

Gambar 8. Nilai PCN Berdasarkan COMFAA pada BIJB Kertajati

Tabel 5. Nilai PCN BIJB

Hasil Perhitungan Nilai PCN BIJB

$\begin{array}{cc}\text { Metode ICAO } & \text { Metode FAA AC } 150 / 5335-5 \mathrm{C} \\ 89 / \mathrm{F} / \mathrm{C} / \mathrm{X} / \mathrm{T} & 101,4 / \mathrm{F} / \mathrm{C} / \mathrm{X} / \mathrm{T}\end{array}$

\subsection{Perhitungan Nilai Aircraft Classification Number}

Aircraft Classification Number (ACN) digunakan untuk menilai pengaruh relatif pada suatu pesawat terhadap permukaan landas pacu. Dalam hal ini artinya, pesawat yang boleh menggunakan landas pacu harus memiliki ACN yang lebih kecil dari PCN. Hasil pengkalkulasian nilai ACN pada Gambar 9 menggambarkan nilai ACN parameter ICAO pada setiap model pesawat yaitu nilai gross weight, gross weight on main gear, tire pressure, ACN thickness maka nilai ACN dari hasil analisis didapat nilai $\mathrm{ACN}<\mathrm{PCN}$. Nilai ACN dominan ialah jenis pesawat B777-300 ER beserta nilai ACN sebesar 89,3. Menurut nilai PCN perkerasan yang lebih besar dibandingkan nilai ACN pesawat rencana, maka dapat disimpulkan bahwa perkerasan landasan BIJB benar-benar aman digunakan untuk kegiatan penerbangan hingga 20 tahun mendatang. Resume analisis tebal perkerasan 5 metode dengan 1 hasil analisis menggunakan FAARFIELD sebagai pembanding 4 metode lainnya.

\begin{tabular}{|c|c|c|c|c|c|}
\hline $\begin{array}{l}\text { Results Table } 3 . \text { Flexible } \\
\text { No. Aircraft Name }\end{array}$ & $\begin{array}{c}\text { AGN at It } \\
\text { Gross } \\
\text { Weight }\end{array}$ & $\begin{array}{c}\text { dicated Gro } \\
\text { \& GW on } \\
\text { Main Gear }\end{array}$ & $\begin{array}{l}5 \text { Weight } \\
\text { Tire } \\
\text { Pressure }\end{array}$ & $\begin{array}{c}\text { and Strer } \\
\text { ACN } \\
\text { Thick }\end{array}$ & $\begin{array}{l}\text { ACN on } \\
C(6)\end{array}$ \\
\hline $1 \mathrm{~A}-320$ Bogie & 73,900 & 93,80 & 1.220 & $563, ?$ & 23,8 \\
\hline (2) A319-100 std & 64,400 & 92,60 & 1.190 & 697,4 & 36,4 \\
\hline (3) B737-900 IR & 85,366 & 94,58 & 1.517 & 866,0 & 56,0 \\
\hline 4. B737-800 & 79,243 & 93,56 & 1.413 & 820,3 & 50,3 \\
\hline $5 \mathrm{B7} 67-300 \mathrm{IR}$ & 187,334 & 92,40 & 1.379 & 937,9 & 65,8 \\
\hline (6) B747-400 & 397,801 & 93,32 & 1.379 & 985,8 & 72,6 \\
\hline (7) B777-300 ER & 352,441 & 92,44 & 1.524 & $1.092,9$ & 89,3 \\
\hline $8 \mathrm{~B} 737-300$ & 63,503 & 90,86 & 1.386 & 720,5 & 38,8 \\
\hline (9) B747-100 SE & 334,751 & 92,48 & 1.600 & 857.7 & 55,0 \\
\hline
\end{tabular}

Gambar 9. Nilai ACN berdasarkan COMFAA pada BIJB Kertajati 
Bahasan mengenai analisis tebal perkerasan landas pacu BIJB Kertajati terdapat 5 data hasil analisis tebal perkerasan landas pacu. Hasil analisis landas pacu tersebut dari 5 data menghasilkan data yang berbeda dari data semula yaitu data eksisting, karena analisis tebal perkerasan yang digunakan pada setiap analisis menggunakan metode yang berbeda. Data tebal perkerasan landas pacu menurut data eksisting memiliki tebal lapisan permukaan (surface) sebesar $200 \mathrm{~mm}$, lapisan fondasi (base course) sebesar $350 \mathrm{~mm}$, lapisan fondasi bawah (subbase course) sebesar $460 \mathrm{~mm}$, dan lapisan tanah dasar (subgrade) ialah 6\%. Data hasil analisis dalam Tugas Akhir ini menggunakan perangkat lunak FAARFIELD didapat tebal setiap lapisan yang dianalisis dengan menambahkan data karakteristik pesawat yang dapat diakses secara langsung dalam perangkat lunak FAARFIELD pada data external dan data asumsi annual departure. Hasil data tebal perkerasan menurut FAARFIELD memiliki tebal lapisan permukaan (surface) sebesar $200 \mathrm{~mm}$, lapisan fondasi (base course) sebesar $127 \mathrm{~mm}$, lapisan fondasi bawah (subbase course) sebesar 487,9 mm, dan lapisan tanah dasar (subgrade) ialah 6\%. Total tebal perkerasan sebesar 814,9 mm. Hasil evaluation thickness mendapatkan total sebesar $1.189 \mathrm{~mm}$ pada metode FAA AC 150/5335-5C melalui perangkat lunak COMFAA, melalui perhitungan menggunakan bantuan spreadsheet. Dari hasil ini menunjukkan data yang signifikan berbeda dari perbandingan data eksisting dengan FAARFIELD ialah pada lapisan fondasi. Bahwa tebal lapisan yang hasil analisis pada penelitian ini dapat ditoleransi ketebalannya dengan data eksisting BIJB Kertajati. Berikut terdapat 3 data pembanding lainnya yang diperoleh dari hasil analisis dengan metode yang berbeda dari (Anis, 2016) dengan metode empiris dan metode mekanistik dan data hasil analisis dari penelitian terdahulu (Putri, 2016) dengan menggunakan perangkat lunak COMFAA.

Data analisis yang diperoleh dari (Anis, 2016) dengan metode empiris memiliki tebal lapisan permukaan (surface) sebesar 152,4 mm, lapisan fondasi (base course) sebesar $368,3 \mathrm{~mm}$, lapisan fondasi bawah (subbase course) sebesar 825,5 mm, dan lapisan tanah dasar (subgrade) ialah 6\%. Metode kedua dari (Anis, 2016) ialah metode mekanistik memiliki tebal lapisan permukaan (surface) sebesar $127 \mathrm{~mm}$, lapisan fondasi (base course) sebesar 457,2 mm, lapisan fondasi bawah (subbase course) sebesar 944,4 mm, dan lapisan tanah dasar (subgrade) ialah 6\%. Data terakhir sebagai pembanding ialah data yang diperoleh dari hasil COMFAA dari penelitian Nurul Aulia Putri pada tahun 2016 memiliki tebal lapisan permukaan (surface) sebesar $127 \mathrm{~mm}$, lapisan fondasi (base course) sebesar 203,2 mm, lapisan fondasi bawah (subbase course) sebesar 1405,4 mm, dan lapisan tanah dasar (subgrade) ialah 6,5\%. 
Semua data hasil analisis memiliki tebal lapisan yang berbeda, namun dapat dilihat bahwa data hasil analisis pada penelitian ini dengan hasil data eksisting BIJB Kertajati tidak jauh berbeda, dalam hal ini data hasil analisis mendekati sesuai dengan perencanaan awal tebal lapisan yang telah diterapkan di landasan pacu BIJB Kertajati. Dengan material yang digunakan lapisan permukaan (surface) ialah P401/P-403 Hot mix aggregate (HMA) Surface, lapisan fondasi (base course) P-304 Cement Treated Base (CTB), lapisan fondasi bawah (subbase course) P-209 Crushed Aggregate, dan lapisan tanah dasar (subgrade).

Tabel 6. Resume Analisis Tebal Perkerasan

\begin{tabular}{|c|c|c|c|c|c|}
\hline Metode & & $\begin{array}{c}\text { Lapisan } \\
\text { Permukaan } \\
(\text { Surface })\end{array}$ & $\begin{array}{c}\text { Lapisan } \\
\text { Fondasi } \\
(\text { Base })\end{array}$ & $\begin{array}{c}\text { Lapisan } \\
\text { Fondasi } \\
\text { Bawah } \\
\text { (Subbase) }\end{array}$ & $\begin{array}{c}\text { Lapisan tanah } \\
\text { dasar } \\
(\text { Subgrade })\end{array}$ \\
\hline \multirow{2}{*}{ Eksisting } & Material & $\begin{array}{l}\text { Asphalt } \\
\text { Concrete }\end{array}$ & $\begin{array}{c}\text { Cement Treated } \\
\text { Base }\end{array}$ & Sirtu & Subgrade \\
\hline & $\begin{array}{l}\text { Tebal } \\
(\mathrm{mm})\end{array}$ & 200 & 350 & 460 & $6 \%$ \\
\hline \multirow{2}{*}{$\begin{array}{c}\text { Hasil COMFAA } \\
\text { (Putri, 2016) }\end{array}$} & Material & $\begin{array}{l}\text { Asphalt } \\
\text { Concrete }\end{array}$ & Aggregate base & Sirtu & Subgrade \\
\hline & $\begin{array}{l}\text { Tebal } \\
(\mathrm{mm})\end{array}$ & 127 & 203,2 & 1405,4 & $6,50 \%$ \\
\hline \multirow{2}{*}{$\begin{array}{c}\text { Hasil Anis, } 2016 \\
\text { (Metode } \\
\text { Empiris) }\end{array}$} & Material & $\begin{array}{l}\text { Asphalt } \\
\text { Concrete }\end{array}$ & Aggregate base & Sirtu & Subgrade \\
\hline & $\begin{array}{l}\text { Tebal } \\
(\mathrm{mm})\end{array}$ & 152,4 & 368,3 & 825,5 & $6 \%$ \\
\hline \multirow{2}{*}{$\begin{array}{c}\text { Hasil Anis, } 2016 \\
\text { (Metode } \\
\text { Mekanistik) }\end{array}$} & Material & $\begin{array}{l}\text { Asphalt } \\
\text { Concrete }\end{array}$ & Aggregate base & Sirtu & Subgrade \\
\hline & $\begin{array}{l}\text { Tebal } \\
(\mathrm{mm})\end{array}$ & 127 & 457,2 & 944,4 & $6 \%$ \\
\hline \multirow{2}{*}{$\begin{array}{l}\text { Hasil Analisis } \\
\text { FAARFIELD }\end{array}$} & Material & $\begin{array}{l}\text { Asphalt } \\
\text { Concrete }\end{array}$ & $\begin{array}{c}\text { Cement Treated } \\
\text { Base }\end{array}$ & Sirtu & Subgrade \\
\hline & $\begin{array}{l}\text { Tebal } \\
(\mathrm{mm})\end{array}$ & 200 & 127 & 487,9 & $6 \%$ \\
\hline
\end{tabular}

Nilai PCN untuk metode ICAO sebesar $89<$ nilai ACN sebesar 89,3. Pada syarat dalam penentuan nilai ACN dan PCN seharusnya $\mathrm{PCN} \geq A C N$. Namun, kenyataannya saat dibandingkan dengan nilai PCN dengan metode ICAO bahwa hasilnya tidak memenuhi syarat. Dalam hal ini, data PCN dengan metode ICAO hanya sebagai hasil analisis saja. Penentuan dalam perencanaan perkerasan landasan pacu di bandar udara, baik perkerasan lentur maupun perkerasan kaku, nilai ACN tidak diperkenankan melewati nilai PCN yang ada. Karena, nilai PCN dan ACN amat esensial untuk memahami kapabilitas perkerasan terhadap pesawat yang bekerja. Pada Tabel 6 dapat dilihat bahwa itu merupakan tabulasi 
resume dari hasil analisis dan data pembanding yang diklasifikasikan atas material yang digunakan serta tebal perkerasan pada masing-masing lapisan.

\subsection{Parameter Biaya Konstruksi Struktur Perkerasan Landas Pacu}

Parameter hasil rancangan struktur landas pacu BIJB Kertajati ialah tebal struktur perkerasan yang dianalisis dengan memperhitungkan biaya konstruksi struktur perkerasan landas pacu yang berpedoman pada Peraturan Menteri nomor 78 tahun 2014 mengenai standar biaya di lingkungan Kementerian Perhubungan. Berikut, pada Tabel 7 merupakan salah satu cara menghitung Biaya Konstruksi dari Hasil Analisis FAARFIELD. Biaya konstruksi yang telah diperhitungkan untuk seluruh metode seperti dapat dilihat pada Tabel 8 yakni analisis biaya konstruksi dengan hasil anggaran ergonomis pada hasil analisis tebal FAARFIELD.

Tabel 7. Biaya Konstruksi dari Hasil Analisis FAARFIELD

\begin{tabular}{|c|c|c|c|c|}
\hline Kegiatan & Unit & Volume & $\begin{array}{l}\text { Harga } \\
\text { Satuan }\end{array}$ & Jumlah \\
\hline \multicolumn{5}{|c|}{ Pekerjaan Pendahuluan } \\
\hline Direksi Keet & ls & 0 & & \\
\hline Mobilisasi dan demobilisasi & ls & 0 & & \\
\hline Pembersihan & $\mathrm{m}^{2}$ & 1 & $14.280,92$ & $14.280,92$ \\
\hline Pengukuran & $\mathrm{m}^{2}$ & 1 & $4.289,79$ & $4.289,79$ \\
\hline \multicolumn{5}{|c|}{ Pekerjaan Konstruksi Perkerasan Baru } \\
\hline \multicolumn{5}{|c|}{ Hasil FAARFIELD } \\
\hline $\begin{array}{c}\text { Sirtu (subbase) } \\
\text { Tebal 487,9 mm }\end{array}$ & $\mathrm{m}^{2}$ & 1 & $86.287,96$ & $561.331,94$ \\
\hline $\begin{array}{c}\text { Lapisan CTBC (base) } \\
\text { Tebal } 127 \mathbf{~ m m}\end{array}$ & $\mathrm{m}^{2}$ & 1 & $289.167,37$ & $489.656,75$ \\
\hline $\begin{array}{c}\text { Prime Coating AC 60/70 (lapis resap } \\
\text { pengikat) }\end{array}$ & $\mathrm{m}^{2}$ & 1 & $39.359,19$ & $39.359,19$ \\
\hline $\begin{array}{c}\text { Lapisan Aspal Beton,AC (surface) } \\
\text { Tebal } 200 \text { mm }\end{array}$ & $\mathrm{m}^{2}$ & 1 & $263.848,58$ & $703.596,21$ \\
\hline Harga/m² (Rp) & & & & $1.812 .514,80$ \\
\hline
\end{tabular}

Tabel 8. Analisis Biaya Konstruksi

\begin{tabular}{cc}
\hline Metode & Biaya Konstruksi (Rp) \\
\hline Kondisi Eksisting & $475.237 .199 .040,00$ \\
COMFAA (Putri, 2016) & $453.983 .763 .206,00$ \\
Metode Empiris (Anis, 2016) & $408.548 .557 .308,00$ \\
Metode Mekanistik (Anis, 2016) & $448.626 .634 .838,00$ \\
Hasil Analisis FAARFIELD & $326.252 .664 .418,00$ \\
\hline
\end{tabular}


Dalam penelitian ini diketahui bahwa perhitungan menggunakan metode Advisory Circular (AC) No.150/5320-6E yang menggunakan perangkat lunak Federal Aviation Administration and Flexible Iterative Elastic Layer Design (FAARFIELD). Total ketebalan dari hasil analisis menggunakan perangkat lunak FAARFIELD didapat tebal lapisan perkerasan lentur sebesar $814,9 \mathrm{~mm}$. Evaluasi ketebalan perkerasan landas pacu dikalkulasi dengan 2 nilai yaitu nilai $\mathrm{PCN}$ dan $\mathrm{ACN}$. Evaluasi ketebalan dengan nilai PCN menggunakan metode ICAO dan metode FAA AC 150/5335-5C yang menggunakan perangkat lunak COMFAA. Didapat nilai PCN terbesar ialah metode FAA sebesar 101,4/F/C/X/T sedangkan metode ICAO sebesar 89/F/C/X/T. Evaluasi nilai ACN terbesar pada jenis pesawat B777-300 ER sebesar 89,3. Sesuai syarat bahwa nilai PCN > ACN. Didapatlah nilai PCN 101,4/F/C/X/T > nilai ACN sebesar 89,3. Hal ini dinyatakan bahwa perkerasan landas pacu BIJB benar-benar aman digunakan untuk operasional pesawat hingga 20 tahun mendatang. Hasil analisis biaya total struktur perkerasan landas pacu yang telah diperhitungkan untuk konstruksi perkerasan yang ergonomis yakni hasil dari FAARFIELD dengan biaya sebesar Rp. 326.252.664.418,00.

\section{KESIMPULAN DAN SARAN}

\subsection{Kesimpulan}

Berlandaskan hasil analisis didapat simpulan sebagai berikut:

1. Hasil analisis FAARFIELD sebagai analisis tebal lapisan struktur perkerasan lentur BIJB Kertajati dengan tebal total didapat sebesar $814,9 \mathrm{~mm}$ dengan tebal lapisan permukaan (surface) sebesar $200 \mathrm{~mm}$, lapisan fondasi (base course) sebesar $127 \mathrm{~mm}$, lapisan fondasi bawah (subbase course) sebesar 487,9 mm, dan lapisan tanah dasar (subgrade) CBR 6\%. Hasil evaluasi nilai ACN-PCN memenuhi syarat ketentuan untuk desain umur rencana 20 tahun. Dengan nilai PCN untuk metode FAA sebesar 101,4/F/C/X/T > Nilai ACN sebesar 89,3.

2. Dari hasil perbandingan total biaya 5 jenis bahasan, yaitu hasil eksisting, hasil analisis COMFAA (Putri, 2016), metode empiris (Anis, 2016), metode mekanistik (Anis, 2016), dan hasil analisis FAARFIELD ternyata hasil dari tebal analisis FAARFIELD menunjukkan biaya total yang terendah.

\subsection{Saran}

1. Saran dalam penelitian tambahan untuk melengkapi hasil penelitian ini dengan melaksanakan analisis jika lapisan permukaan menggunakan perkerasan kaku. 
2. Menganalisis dengan metode lain seperti metode Portland Cement Association (PCA) dasan metode asphalt institute.

\section{DAFTAR PUSTAKA}

1. Anis, M., 2016, Analisis Perbandingan Metode Empiris Dan Metode Mekanistik Dalam Perancangan Landasan Bandar Udara (Studi Kasus Bandar Udara Kertajati - Majalengka), Direktoral Jenderal Perhubungan Udara, Kementrian Perhubungan.

2. Brill, D..,2016, Updates To FAA Advisory Circular 150/5320-6, Federal Aviation Administration.

3. Company, 2016, Bandar Udara Internasional Jawa Barat, BIJB, In BIJB Airport And Aerocity.

4. Horronjeff, R. F. ., 1988, Perencanaan Dan Perancangan Bandar Udara. Edisi Ke3. Jakarta: Terjemahan Oleh: Erlangga.

5. ICAO, 2016, International Civil Aviation Organization.

6. Basuki, H., 1986, Merancang, Merencana Lapangan Terbang.

7. Perhubungan, M. (2014). Standar Biaya di Lingkungan Kementrian Perhubungan. Menteri Perhubungan Republik Indonesia NOMOR. PM 78 TAHUN 2014 (p. 190). Jakarta: Menteri Perhubungan.

8. Putri, N. A. (2016). Analisis Kekuatan Perkerasan Landas Pacu Bandar Udara Internasional Jawa Barat Dengan Perangkat Lunak COMFAA. Tugas Akhir Universitas Kristen Maranatha.

9. Susilo, B.H., 2014, Dasar-dasar Rekayasa Transportasi, Universitas Trisakti, Jakarta.

10. U.S. Department Of Transportation Federal Aviation Administration, 2016, Airport Pavement Design And Evaluation, Federal Aviation Administration AC 150/5320-6f. 